\title{
STRATEGI EPISTIMOLOGIS IMPLEMENTASI PENDIDIKAN HOLISTIK PADA PONDOK PESANTREN
}

\author{
Muhammad Nasruddin')*), Hilman Harun²), Ahmad Salim3), \\ Ahmad Dimyati4) \\ 1,2)Universitas Cokroaminoto Yogyakarta, 3)Universitas Alma Atta, \\ 4)Institut Pesantren Mathaliul Falah \\ 1)mohn98294@gmail.com, 2)hilharuno2@gmail.com, 3)kriwel99@yahoo.com, \\ 4)dimyati@ipmafa.ac.id \\ *Penulis koresponden

\begin{tabular}{|l|l|l|}
\hline Diajukan: 30-05-2021 & Diterima: 09-06-2021 & Diterbitkan: 12-06-2021
\end{tabular}

\begin{abstract}
Islamic boarding school education, namely; Al Muhafadhah ala al-qadim al shalih wa al akhdzu bi al jadid al ashlah. This principle has encouraged pesantren to maintain good old Islamic values without denying better changes. This paper intends to explore two sides of the coin for Pondok Persantren where one side is a distinct advantage for but can be a boomerang that hinders the progress of Islamic education based on understanding the basic elements and values of Islamic boarding schools and, then contributing thoughts in building a holistic Islamic boarding school education so that can follow the development of science without losing the obligation to maintain basic values. Holistic pesantren education can only be achieved if it is reaffirmed that the elements of the boarding school education system are not oriented towards learning religious knowledge but how kyai, teachers / ustaz and santri can learn to live in religion.
\end{abstract}

Keywords: epistemological strategy, implementation, holistic education, pondok pesantren

abstrak: prinsip dasar pendidikan pondok pesantren, yaitu; $A l$ Muhafadhah ala al-qadim al shalih wa al akhdzu bi al jadid al ashlah. Kaidah itu telah mendorong pesantren untuk tetap eksisnya nilai-nilai keislaman lama yang baik dengan tidak menafikan perubahan-perubahan yang lebih baik. Tulisan ini bermaksud mengeksplorasi dua sisi mata uang bagi Pondok Persantren itu dimana Satu sisi menjadi kelebihan tersendiri bagi tetapi bisa menjadi boomerang yang menghambat kemajuan pendidikan Islam berdasarkan pemahaman unsur dan nilai dasar tentang pondok pesantren dan, kemudian memberikan sumbangan pemikiran dalam membangun pendidikan pondok pesantren holistik sehingga dapat mengikuti perkembangan ilmu tanpa kehilangan kewajiban untuk mempertahankan nilai dasar. pendidikan pesantren yang holistik hanya bisa dicapai apabila penegasan kembali bahwa unsur system pendidikan pondok pesantren tidak berorientasi belajar ilmu agama tetapi bagaimana kyai, guru/ustaz dan santri bisa belajar hidup beragama. 
Keyword: strategi epistimologis, implementasi, pendidikan holistik, pondok pesantren

\section{A. Pendahuluan}

Pendidikan pesantren dan kehidupan kebangsaan Indonesia sudah tak terbantahkan. Di zaman kerajaan Islam sebelum kolonialisme membelenggu Nusantara, Soebardi dan John dalam Dhofier menjelaskan :
"Lembaga-lembaga pesantren itulah yang paling menentukan watak keislaman dari kerajaan-kerajaan Islam, dan yang memegang peranan paling penting bagi penyebaran Islam sampai ke pelosok-pelosok. Dari lembaga-lembaga pesantren itulah asal-usul sejumlah manuskrip tentang pengajaran Islam di Asia Tenggara yang tersedia secara terbatas, yang dikumpulkan oleh pengembara-pengembara pertama dari perusahaan- perusahaan dagang Belanda dan Inggris sejak berakhir abad ke-16. Untuk dapat betul-betul memahami sejarah Islamisasi di wilayah ini, kita harus mulai mempelajari lembaga-lembaga pesantren tersebut, karena lembaga inilah yang menjadi anak panah penyebaran Islam di wilayah ini."1

Dalam perjalanan perubahan nusantara menjadi Negara Kesatuan Republik Indonesia, peran pesantren tetap menjadi sandaran penting tak sebatas penyebaran Islam. Area telah diperluas melalui pengobaran semangat jihad melawan penjajahan dan pembentukan pemerintahan yang merdeka dan berdaulat. Rahardjo kemudian menyimpulkan, selain merupakan pendidikan Islam tertua dan memegang peran penting dalam penyebaran Islam di Indonesia. Pesantren telah menjadi unsur dominan dalam menentukan keberlangsungan hidup bangsa Indonesia. ${ }^{2}$ Majid menguatkan aspek kebangsaan itu dengan menjelaskan cita-cita Ki Hajar

${ }_{1}$ Zamakhsyari Dhofier, Tradisi Pesantren; Studi tentang Pandangan Hidup Kyai, 4 ed. (Jakarta: LP3ES, 1985), 17-18.

2 Imroatun Imroatun, "Kontribusi Lembaga Pendidikan Agama Islam Dalam Penguatan Identitas Bangsa," Jurnal Ilmiah Bidang pendidikan Studia Didaktika 8, no. 1 (2016); Nur Cholish Madjid, Bilik-bilik Pesantren; Sebuah Potret Perjalanan (Jakarta: Paramadina, 2010). 
Dewantara yang telah mengadaptasinya sebagai model sistem pendidikan di Indonesia. ${ }^{3}$

Kelebihan pesantren tak lepas dari salah satu prinsip dasar pendidikannya, yaitu; "Al Muhafadhah ala al-qadim al shalih wa al akhdzu bi al jadid al ashlah.” Kaidah itu telah mendorong pesantren untuk tetap eksisnya nilai-nilai keislaman lama yang baik dengan tidak menafikan perubahan-perubahan yang lebih baik. Konsep Al-Muhafadhah atau mempertahankan tradisi yang ada di pesantren telah menjadi dua sisi mata uang bagi pesantren. Satu sisi menjadi kelebihan tersendiri bagi tetapi bisa menjadi boomerang yang menghambat kemajuan pendidikan Islam yang menjadi tugas utamanya. ${ }^{4}$

Namun dewasa ini telah muncul banyak kritikan terhadap pendidikannya. Salah satunya adalah Nugroho yang mengharapkan proses reorientasi pendidikannya yang dualistik antara madrasah dan pesantren kembali pada semangat partisipatif dalam persoalan masyarakat ${ }^{5}$. Kritikan terhadap pola pendidikan Islam dalam pesantren ini mengarahkan pada problem epistimologis yang harus diperbaiki. Hal itu juga dipertegas oleh Amin Abdullah, "Loyalitas faham menjadi permasalahan mendasar yang belum menyentuh bangunan epistemologi keilmuan terutama keilmuan klasik maupun sosial keagamaan yang berkembang hingga saat ini.”6

Tulisan ini bermaksud mengeksplorasi masalah itu berdasarkan pemahaman unsur dan nilai dasar tentang pesantren dan, kemudian memberikan sumbangan pemikiran dalam membangun pendidikan pesantren holistik sehingga dapat mengikuti perkembangan ilmu tanpa kehilangan kewajiban untuk mempertahankan nilai dasar agama Islam yang berdaya guna bagi masyarakat.

3 M. Dawam Raharjo, ed., Pesantren dan Pembaharuan, 5 ed. (Jakarta: LP3ES, 1985), vii.

4 Umi Musaropah et al., "Internalisasi Nilai Luhur Ahlu Sunnah wal Jama'ah Bagi Pengembangan Karakter kebangsaan Di Perguruan Tinggi," Nuansa Akademik: Jurnal Pembangunan Masyarakat 5, no. 2 (Desember 26, 2020): 89-102.

5 Taufik Nugroho, "Reorientasi Peranan Pesantren Pada Era Pembangunan Menuju Partisipasi Pemberdayaan Masyarakat Bawah," Ulumuddin: Jurnal Ilmu-ilmu Keislaman 7, no. 2 (2017): 147-155.

6 M. Amin Abdullah, Falsafah Kalam Di Era Post Modernisme, (Yogyakarta, Pustaka Pelajar, 1997), 264. 


\section{B. Metode}

Tulisan ini bermaksud memperjelas perkembangan teoritis dan empirik tentang pendidikan pesantren bagi kemajuan kebangsaan di Indonesia berdasar tinjauan literatur. Karena keragaman bentuk pesantren dan pola pendidikan masing-masing, ${ }^{7}$ maka dalam penelitian ini dibatasi pada pesantren salaf yang lebih bercorak tradisional dengan kekuatan kharisma kyai. ${ }^{8}$ Data literer kemudian diolah melalui analisis filosofis. Uraian diawali dengan pemberian pemahaman tentang pondok pesantren terutama yang memiliki tipikal salaf. Deskripsi pesantren dalam konteks ke-Indonesiaan kemudian dijabarkan sebelum kaitan pesantren dan pendidikan holistik dirumuskan dalam perspektif filsafat pendidikan dalam uraian selanjutnya untuk menemukan strategi pengembangannya secara epsitimologis.

\section{Pondok Pesantren, Pendidikan Islam Khas Indonesia}

Prasodjo dkk mengartikan pesantren adalah "lembaga pendidikan dan pengajaran agama Islam, umumnya dengan cara non klasikal, di mana seorang Kyai mengajarkan ilmu agama Islam kepada santri-santri berdasarkan kitab-kitab yang ditulis dalam bahasa Arab oleh ulama abad pertengahan, dan para santri biasanya tinggal di pondok (asrama) dalam pesantren tersebut."9 Arifin setuju dengan penekanan Prasojo dkk. dalam membatasi pengertian pesantren pada subyek, obyek dan materi pendidikannya dengan menyatakannya sebagai "pranata pendidikan tradisional yang dipimpin oleh seorang kyai. Di pesantren inilah para santri dihadapkan dengan berbagai cabang ilmu agama yang bersumber dari kitab-kitab kuning." ${ }^{\circ}$ Mastuhu ternyata mengartikannya lebih dalam dan detil hingga wilayah nilai-nilai yang berkembang dalam komunitas pendidikan tua ini. Baginya, “pesantren dalam penyelenggaraan

7 Husen Hasan Basri, "Keragaman Orientasi Pendidikan Di Pesantren," Dialog 37, no. 2 (Desember 2014): 207-220; Ahmad Nadjib et al., "Penanaman Nilai-Nilai Kemasyarakatan Di Pesantren Modern," Nuansa Akademik: Jurnal Pembangunan Masyarakat 4, no. 1 (Juni 25, 2019): 17-32.

8 Umi Musaropah, "Kharisma Kyai Dalam Organisasi Pendidikan Pesantren Tradisional," Ulumuddin: Jurnal Ilmu-ilmu Keislaman 8, no. 2 (2018): 141-155; Basri, "Keragaman"

9 Sudjoko Prasodjo dkk, Profil Pesantren, (Jakarta : LP3ES, cet. III, 1983), 6.

${ }^{10}$ Arifin, Pendidikan Islam dan Umum, ( Jakarta : Bumi Aksara, 1991), 248 
pendidikannya berbentuk asrama yang merupakan komunitas khusus di bawah pimpinan kyai dan dibantu oleh ustadz yang berdomisili bersamasama santri dengan masjid sebagai pusat aktivitas belajar mengajar, serta pondok atau asrama sebagai tempat tinggal para santri dan kehidupan bersifat kreatif, seperti satu keluarga."11

Pengertian Mastuhu memberi kejelasan bahwa pesantren bukanlah semata lembaga pendidikan akademis mengajarkan ilmu agama tetapi telah berjalan lebih jauh hingga pendidikan kehidupan beragama. Kyai memang mengajar ilmu-ilmu agama yang tercakup dalam kitab-kitab kuning, pada awal perkembangannya, di masjid yang sekaligus menjadi tempat ibadah bersama bagi seluruh penghuni pesantren. Ketika santri berjumlah banyak dan beragam, maka didirikanlah kelas-kelas. Kyai pun mendelegasikan tugas pendidikannya kepada guru dan ustaz. Meski demikian, kemajuan itu tidak merubah eksistensi masjid sebagai pusat kegiatan di pesantren karena seluruh penghuninya tetap pergi ke masjid sebagai pusat ibadah dan menerima ajaran maupun tausiyah secara langsung dari Kyai. Masjid juga menjadi pusat hubungan hidup beragama antara para penghuni dengan dunia social di sekitarnya. Dari gambaran dan definisi pesantren, unsur pokoknya adalah Kyai, santri, mesjid dan pondok, dan system pendidikannya.

Kyai

Keberadaan seorang Kyai dalam lingkungan sebuah pesantren, adalah laksana jantung bagi kehidupan manusia. Begitu urgen dan esensialnya kedudukan Kyai. Karena dialah perintis pendiri, pengelola, pengasuh, pemimpin dan terkadang juga pemilik tunggal sebuah pesantren. Itulah sebabnya, banyak pesantren akhirnya bubar, lantaran ditinggal wafat Kyainya, sementara dia tidak memiliki keturunan yang dapat meneruskan perjuangannya.

Kyai adalah seorang tokoh yang berwibawa, baik di hadapan para ustaz, dihadapan santri, bahkan juga di hadapan istri dan anak-anaknya. Ketaatan para santri kepada Kyai bukan karena paksaan, tetapi didasari

${ }^{11}$ Mastuhu, Dinamika Sistem Pendidikan Pesantren, (INIS:Jakarta, 1994), 6 
dengan motivasi pengakuan terhadap status kyai yang diberikan oleh masyarakat yang mengakui kealimannya, menyaksikan peranan dan merasakan jasanya serta menerima tuntutan serta kepemimpinannya.

Sebutan Kyai untuk pendiri dan pemimpin pesantren sesungguhnya ini berasal dari daerah Jawa Timur dan Jawa Tengah. Namun kini telah mulai populer di Jawa Barat, Jakarta dan daerah-daerah lain di luar Jawa. Kyai pendiri dan pemimpin pesantren di Jawa Barat di sebut dengan Ajengan, di Sumatera Barat disebut Abuya, di Aceh disebut Encik di Madura disebut Bendara yang disingkat dengan $R a .^{12}$

Menurut asal-usulnya, perkataan Kyai dalam bahasa Jawa dipakai untuk tiga jenis gelar yang saling berbeda. "Sebagai gelar kehormatan bagi barang-barang yang dianggap keramat; umpamanya, Kyai Garuda Kencana dipakai untuk sebutan kereta emas yang ada di Keraton Yogyakarta. Gelar kehormatan untuk orang-orang tua pada umumnya. Gelar yang diberikan oleh masyarakat kepada seorang ahli agama Islam yang memiliki atau menjadi pimpinan pesantren dan mengajar kitab-kitab Islam klasik kepada para santrinya. Selain gelar Kyai, ia juga sering disebut seorang alim (orang yang dalam pengetahuan Islamnya).”13

Batasan demikian ternyata tidaklah ketat. Banyak para ulama berpengaruh di masyarakat masih disebut Kyai walaupun mereka tidak memimpin pesantren. maka status Kyai mengandung makna pemuliaan dan penghormatan yang diberikan oleh masyarakat secara suka rela kepada seorang pemimpin pesantren, ulama Islam, pemimpin masyarakat Islam setempat, yang tidak dapat diperoleh melalui pendidikan formal atau bukan merupakan gelar akademis.

Gelar atau sebutan Kyai diperoleh seseorang kemudian berkat kedalaman ilmu keagamaannya, kesungguhan perjuangannya untuk kepentingan Islam, keikhlasannya, keteladanannya di tengah umat, kekhusyukannya dalam beribadah, dan kewibawaannya sebagai 
pemimpin. Sebagaimana dikemukakan oleh Ali,14 "Semata karena faktor pendidikan tidak menjamin bagi seseorang untuk memperoleh predikat Kyai, melainkan faktor bakat dan seleksi alamiah yang lebih menentukannya." Chirzin ketika menyimpulkan alasan mengapa sebagian pesantren besar tetap tidak memberikan ijasah juga berpendapat sama. "Karena hal itu dianggap kurang penting, dan yang lebih penting adalah kealiman, keshalehan dan kecakapan santri dan masyarakatlah yang akan memberikan ijasah." ${ }^{15}$

Masjid

Secara etimologis, "masjid diambil dari kata dasar sujud yang berarti ta'at, patuh, tunduk dengan penuh rasa hormat dan takzim. Sedangkan secara terminologis, dalam hukum Islam (fiqh), sujud itu berarti adalah meletakan dahi berikut ujung hidung (tulang T), kedua telapak tangan, kedua lutut dan kedua ujung jari kaki ke tanah, yang merupakan salah satu rukun shalat. Sujud dalam pengertian ini merupakan bentuk lahiriyah yang paling nyata dari makna-makna etimologis di atas. Itulah sebabnya, tempat khusus penyelenggaraan shalat disebut dengan masjid." Syafe’i melanjutkan penjelasannya. Dari pengertian sujud secara terminologis di atas, maka masjid dapat didefinisikan sebagai "suatu bangunan, gedung atau suatu lingkungan yang memiliki batas yang jelas (benteng/pagar) yang didirikan secara khusus sebagai tempat beribadah umat Islam kepada Allah SWT, khususnya untuk menunaikan shalat." 16

Sejarah awal Islam ternyata memperlihatkan keluasan fungsi masjid. Pada masa Rasulullah hingga sahabat, masjid masih memiliki dua fungsi. Pertama, fungsi keagamaan, sebagai pusat atau tempat peribadatan seperti shalat, zikir, doa dan iktikaf. Kedua, fungsi sosial, sebagai pusat pembinaan, pendidikan, pengajaran umat Islam. "Termasuk dalam fungsi kedua ini, di masa shahabat, juga digunakan sebagai pusat administrasi

14Mukti Ali, Pondok Pesantren Dalam Sistem pendidikan nasional, Dalam Beberapa persoalan agama Dewasa Ini, (Jakarta : Penerbit Rajawali, 1987), 15.

15 M. Habib Chirzin, Agama, Ilmu dan Pesantren, in Raharjo, Pesantren, 92.

16 Makhmud Syafei, Masjid Dalam Prespektif Sejarah Dan Hukum Islam (Bandung, n.d.). 
pemerintahan, tempat konsultasi dan komunikasi masalah-masalah keummatan, tempat santunan sosial, markas pertahanan dan keamanan, tempat pengobatan korban perang, tempat perdamaian dan penyelesaian persengketaan, tempat permusyawaratan keagamaan, tempat penerimaan tamu negara." ${ }^{17}$

Di lingkungan pesantren, masjid memang bukan satu-satunya bangunan; karena sekitarnya masih ada atau banyak lagi yang lain. Misalnya, madrasah, kelas bahkan bangunan laian yang tidak berkaitan dengan ibadah secara langsung pun bisa ditemukan. Kondisi ini tidak memberikan tekanan bahwa fungsi masjid telah berubah. Masjid tetap merupakan sentral sebuah pesantren dimana fungsi masjid tetap bagi pelaksanaan shalat berjama'ah, melakukan wirid dan do'a, iktikaf, tadarrus Qur'an dan sejenisnya. Di kesempatan lain, masjid dipergunakan sebagai sentral kegiatan pengajaran, misalnya dengan sistem sorogan dan weton yang biasanya mengambil tempat secara rutin di bagian serambi muka. Di luar jam pelajaran, di serambi yang sama sering dipakai untuk syawir, semacam kegiatan diskusi di kalangan santri. Al-'Abdi pun menegaskan multifungsi masjid menjadi tempat yang paling baik bagi kegiatan pendidikan dan pembentukan moral keagamaan. "Dengan memusatkan segala aktifitas umat Islam di masjid, akan tampak hidupnya sunnah-sunnah Islam dan berkembangnya kehidupan yang sesuai dengan hukum Allah."18

Santri

Kata pesantren menjadi kata derivatif dari kata santri. Dari sisi bahasa, santri telah menunjukkan arti penting santri dalam lembaga pendidikan pesantren. "Santri gabungan dari suku kata sant (manusia baik) dengan suku kata tra (suka menolong), sehingga kata santri dapat berarti manusia baik-baik." ${ }^{19}$

Santri merupakan elemen penting dalam suatu lembaga pesantren. Menurut tradisi pesantren terdapat dua kelompok santri. "Santri mukim 97-98.

17 Manfred Ziemek, Pesantren Dalam Perubahan Sosial (Jakarta: P3M, 1986),

18 Wahyoetomo, 46-47

19 Ziemek, Pesantren 
yaitu murid-murid yang berasal dari daerah yang jauh dan menetap di pesantren. Diantara mereka yang paling lama tinggal di pesantren biasanya merupakan satu kelompok sendiri yang memegang tanggung jawab mengurusi kepentingan pesantren sehari-hari; mereka juga memikul tanggung jawab mengajar santri-santri muda tentang kitab-kitab dasar dan menengah. Santri kalong lain lagi. Yaitu murid-murid yang berasal dari desa-desa di sekeliling pesantren, yang biasanya tidak menetap dalam pesantren. Untuk mengikuti pelajarannya di pesantren, mereka bolak balik dari rumah sendiri. perbedaan antara pesantren besar dengan pesantren kecil biasanya dapat dilihat dari jumlah santri kalong. Semakin besar sebuah pesantren, akan semakin besar jumlah santri mukimnya. Dengan kata lain, pesantren kecil akan memiliki lebih banyak santri kalong daripada santri mukim."

Seorang santri yang menetap di pesantren bisa disebabkan karena berbagai alasan. Demikian yang diutarakan oleh Ziemek. "Ia ingin mempelajari kitab-kitab yang membahas Islam secara lebih mendalam di bawah bimbingan Kyai yang memimpin pesantren tersebut. Ia ingin memperoleh pengalaman kehidupan pesantren, baik dalam bidang pengajaran, keorganisasian maupun hubungan dengan pesantrenpesantren yang terkenal. Ia ingin memusatkan studinya di pesantren tanpa disibukkan oleh kewajiban sehari-hari di rumah keluarganya. Di samping itu, dengan tinggal di sebuah pesantren yang sangat jauh letaknya dari rumahnya sendiri ia tidak mudah pulang-balik meskipun kadang menginginkannya." ${ }^{20}$

Pondok

Dalam karya yang sama, Ziemek menyimpulkan, "Kata pondok berasal dari bahasa Arab funduq yang berarti ruang tidur atau wisma sederhana, karena pondok merupakan tempat penampungan sederhana bagi pelajar yang jauh tempat tinggalnya." 21 bagi Prasodjo, "kata pondok (kamar, gubug, rumah kecil) dipakai dalam bahasa Indonesia dengan

20 Ibid.

${ }^{21}$ Ibid. 
menekankan pada kesederhanaan bangunan."22 Ziemek dan Soedjoko Prasodjo sepakat memberi tekanan yang sama pada kesederhanaan untuk menunjukkan bahwa pendidikan pesantren seharusnya tidak belajar ilmu agama semata namun juga belajar nilai-nilai universal hidup beragama seperti yang diutarakan dalam pengertian Mastuhu tentang pesantren. Namun ada tekanan yang berbeda dari Poerbawakatja; "Pondok adalah suatu tempat pemondokan bagi pemuda-pemudi yang mengikuti pelajaran-pelajaran agama Islam.”23

Pengertian terakhir memperjelas bukti pesantren sebagai pendidikan islam tradisional seperti yang diutarakan oleh Bik dalam Imam Bawani. "Suatu pesantren dikatakan lembaga pendidikan Islam tradisional jika memiliki pondok atau asrama santri yang berstatus mukim. Kecenderungan untuk berkelana dalam menuntut ilmu dan menetap di sebuah tempat dimana seorang guru berada, merupakan tradisi yang menyatu dengan ulama masa lalu."24

Ada beberapa alasan pokok mengapa pondok dalam suatu pesantren ini penting. "Pertama, banyaknya santri-santri yang berdatangan dari daerah yang jauh untuk menuntut ilmu kepada seorang Kyai yang sudah termasyhur keahliannya. Kedua, pesantren-pesantren tersebut terletak di desa-desa, dimana tidak tersedia perumahan santri yang berdatangan dari luar daerah. Ketiga, Ada hubungan timbal balik antara Kyai dan santri, dimana para santri menganggap Kyai sebagai orang tuanya sendiri." ${ }^{25}$

Berapa jumlah unit bangunan pondok atau jumlah kamar secara keseluruhan yang ada atau tersedia pada setiap pesantren, tidak bisa ditentukan. Oleh karena pada umumnya pondok-pondok itu pembangunannya tahap demi tahap, seiring dengan banyaknya santri yang masuk dalam menuntut ilmu di pesantren itu, bahkan terkadang dari

${ }^{22}$ Prasodjo dkk., Profil, 11

${ }_{23}$ Soegarda Poerbakawatja, Ensiklopedi Pendidikan, Cet. III, (Jakarta: CV. Gunung Agung, 1982), 287

24 Imam Bawani, Pesantren Tradisional, (Al-Ikhlas ,Surabaya, 1983), 129

25 Haidar Putra Daulay, Historisitas dan Eksistensi Pesantren, Sekolah dan Madrasah, (Yogyakarta : Tiara Wacana, 2000), 16. 
kalangan mereka sendirilah tenaga dan biaya pembangunannya setelah restu dan persetujuan kyai.

Abdurrahman Wahid secara spesifik menjelaskan bahwa "pondok sebagai tempat tinggal para santri menjadi penting karena kegiatan di pesantren berputar pada pembagian periode berdasarkan pada pembagian waktu sembahyang wajib yang lima (salat rawatib)." ${ }^{26}$ Dengan adanya pondok, maka suasana belajar santri, baik yang bersifat intra kurikuler dan ekstra kurikuler dapat dilaksanakan secara efektif. Santri dapat dikondisikan dalam suasana belajar sepanjang hari dan malam. Pondok bagi santri; seperti yang digambarkan oleh Kartodirjo; "memudahkan untuk memperoleh pengajaran dasar tentang Islam akan tetapi juga memberikan latihan dalam cara hidup dan cara berfikir orang Islam.” ${ }^{27}$ Sistem Pendidikan.

Dalam pendidikan pesantren, Kyai seringkali mempunyai kekuasaan mutlak. Berjalan atau tidaknya kegiatan apapun di pesantren, tergantung pada izin dan atau restu Kyai. Untuk menjalankan kepemimpinannya, unsur kewibawaan memegang peranan penting. ${ }^{28}$

Pendidikan Kyai dalam sistem pendidikan pesantren menganut tradisionalis-konservatif dalam arti orientasi budaya dan sikap pemikirannya, lembaga-lembaga pendidikannya lebih banyak terpusat pada pengembangan ilmu-ilmu agama klasik mulai dari pendidikan dasar, dari pesantren sampai perguruan Tinggi. ${ }^{29}$ pengajaran kitab-kitab klasik merupakan hal paling penting dalam suatu pesantren. Kitab-kitab klasik lebih populer dengan sebutan kitab kuning, yang ditulis oleh ulama'ulama' zaman pertengahan. Kepintaran dan kemahiran seorang santri diukur dari kemampuannya membaca serta mensyarahkan isi kandungan kitab-kitab tersebut.

Kitab-kitab klasik yang biasanya diajarkan di pesantren dapat digolongkan kedalam 8 kelompok: "a. Nahwu (syntax) dan sharaf

${ }^{26}$ Raharjo, Pesantren, 40

${ }_{27}$ Sartono Kartodirjo, Pemberontakan Petani Banten 1888, Terj. Hasan Basari, (Jakarta : Pustaka Jaya, 1984), 223. Tradisional."

28 Musaropah, "Kharisma Kyai Dalam Organisasi Pendidikan Pesantren 29Ibid, 133-134. 
(morfologi), b. fiqh. c. ushul figh. d. hadits. e. tafsir. f. tauhid. g. tasawwuf. h. tarikh dan balaghah. ${ }^{30}$ Kitab- kitab tersebut meliputi teks yang sangat pendek sampai teks yang terdiri dari berjilid-jilid tebal mengenai hadits, tafsir, fikih, ushul fikih dan ajaran tasawwuf. Kesemuanya ini dapat pula digolongkan kedalam tiga kelompok yaitu: 1. kitab-kitab dasar, 2. kitabkitab menengah, 3. kitab-kitab besar.”

Pengelolaan pendidikan dan pengajaran di pesantren salaf sekarang ini dapat dipetakan kepada tiga bentuk akibat perkembangan ilmu pengetahuan modern, yaitu; “(1) Pesantren adalah lembaga pendidikan dan pengajaran agama Islam, yang pada umumnya pendidikan dan pengajarannya diberikan dengan cara non-klasikal bersistem bandongan dan sorogan, di mana seorang kyai mengajar santri-santri berdasarkan kitab-kitab yang ditulis dalam bahasa Arab oleh para ulama besar pada abad pertengahan; sedangkan para santri biasanya tinggal dalam pondok atau asrama dalam tersebut; (2) Pesantren adalah lembaga pendidikan dan pengajaran agama Islam yang pada dasarnya sama dengan pondok pesantren di atas, tetapi para santrinya tidak disediakan pondokan di komplek pesantren, namun tinggal tersebar di sekitar desa sekeliling pesantren tersebut atau santri kalong. Cara dan metode pendidikan dan pengajaran agama Islam diberikan dengan sistem weton, yaitu para santri datang berduyun-duyun pada waktu-waktu tertentu seperti pengajian hari Jum'at, Selasa atau hari-hari tertentu, (3) Pesantren dewasa ini merupakan lembaga gabungan antara sistem pondok dan pengajaran agama Islam dengan sistem bandongan atau wetonan, sorogan, dengan para santri disediakan pondokan ataupun merupakan santri kalong yang dalam istilah pendidikan pesantren modern memenuhi kriteria pendidikan nonformal serta menyelenggarakan juga pendidikan formal berbentuk madrasah dan bahkan sekolah umum dalam berbagai tingkatan dan aneka jurusan menurut kebutuhan masyarakat." ${ }^{31}$

\footnotetext{
30 Dhofier, Tradisi, 50.

31 Taufik Nugroho, "Analisis Manajemen Pendidikan Terhadap Kualitas Madrasah Indonesia," Ulumuddin: Jurnal Ilmu-ilmu Keislaman 6, no. 2 (2016): 80-87; Ahlan Abdullah Solo, Taufik Nugroho, dan Difla Nadjih, "Upaya Santri Dalam Pemeliharaan Hafal Al- Qur'an Di MANU Kota Gede Yogyakarta," Ulumuddin: Jurnal
} 
Pesantren sekarang kebanyakan telah memasukkan pengajaran pengetahuan umum sebagai suatu bagian penting dalam pendidikan pesantren, namun pengajaran kitab-kitab Islam klasik tetap diberikan sebagai upaya untuk meneruskan tujuan utama pesantren mendidik caloncalon ulama' yang setia kepada faham Islam tradisional salaf. Majid menambahkan penerimaan nilai-nilai baru, dalam hal ini kebudayaan asing, tetapi dilakukannya tidak secara formal sebagai sesuatu yang prinsipal, sehingga masih stagnan. ${ }^{2}$ Permasalahan itu telah menyebabkan inkonsistensi dalam mempertahankan prinsip al-muhafadahah.

Usa dkk mencatat beberapa hal yang perlu dibenahi: 33 "pertama, dari segi kepemimpinan pesantren yang masih sentralistik dan otoriter pada seorang kiyai. Pembaharuan pada masalah ini menjadi hal yang sangat sulit dilakukan karena sangat tergantung pada sang kiyai; kedua, kelemahan di bidang metodologi. Meski pesantren mempunyai tradisi kuat di bidang pengkajian keilmuan klasik, karena kekurangan metodologi, yang terjadi adalah penumpukan keilmuan. Ilmu yang bersangkutan dianggap sesuatu yang sudah final dan tidak dapat ditambah. Tradisi pengajaran semacam ini berdampak pada lemahnya kreatifitas. ketiga, terjadinya dis-orientasi, yakni pesantren kehilangan kemampuan mendefinisikan dan memposisikan diri di tengah realitas perubahan sosial yang demikian cepat.”

Dalam kontek perubahan ini, pesantren mengalami dilema dalam keharusan mempertahankan jati dirinya. Sementara kebutuhan menyerap budaya baru yang datang dari luar pesantren juga semakin mendesak. Bila tidak, fenomena pesantren hanya berfungsi sebagai cagar budaya akan menjadi umum.

\section{Strategi Pengelolaan Pendidikan Pesantren Holistik}

Ilmu-ilmu Keislaman 8, no. 2 (2018): 131-140; Muhammad Musodiqin, Difla Nadjih, dan Taufik Nugroho, "Implementasi Sorogan Dalam Pembelajaran Al-Qur'an Pada Madrasah Diniyah Takmiliyah," Ulumuddin: Jurnal Ilmu-ilmu Keislaman 7, no. 1 (2017).

${ }^{2}$ Nurcholis Madjid, Islam Kemodernan dan Keindonesiaan, (Bandung, Mizan, 1998), 112.

33Muslih Musa, Pendidikan Islam di Indonesia, (Yogyakarta: PT Tiara Wacana, 1991), 114-115. 
Tiga gagasan upaya pembaharuan pendidikan Islam telah muncul, yaitu; “(1) Pola pembaharuan pendidikan Islam yang berorientasi kepada pola pendidikan Barat modern. Dengan pertimbangan bahwa kemajuan Barat adalah sebagai hasil dari perkembangan ilmu pengetahuan dan teknologi modern yang mereka capai sebagai warisan dari Islam; (2) Pola pembaharuan pendidikan Islam yang berorientasi pada sumber Islam yang murni, berpandangan bahwa Islam merupakan sumber bagi kemajuan dan perkembangan peradaban dan ilmu pengetahuan modern. Islam telah membuktikannnya pada masa-masa kejayaannya; (3) Pola pembaharuan pendidikan Islam yang berorientasi pada nasionalisme. Rasa nasionalisme di Barat ternyata membawa pada kemajuan, mendorong bangsa-bangsa terjajah untuk mengembangkan nasionalisme masing-masing." 34

Bagi pesantren yang memilih pertama menjadikan sistem pendidikannya menitikberatkan pada pengetahuan umum tetapi mengalami krisis di bidang keagamaan. Santri menjadi manusia-manusia yang memililiki kecerdasan intelektual, namun isi spiritual kering. Pilihan kedua mengarah kepada kebalikan dari yang pertama secara kontras. Keputusan dengan tetap menganut sistem pendidikan tradisional yang berarti menolak kenyataan bahwa sistem tersebut tidak sesuai jaman dan tidak mempunyai daya saing dalam kehidupan bermasyarakat.

Pemikiran Ziauddin Sardar tentang integrasi ilmu pengetahuan memberikan dasar yang dapat dipertimbangkan dalam memelihara konsistensi pinsip al-Muhafadah pesantren. "Pertama, dari segi epistemologi umat Islam harus berani mengembangkan kerangka pengetahuan masa kini yang terartikulasi sepenuhnya. Ini berarti kerangka pengetahuan yang dirancang harus aplikatif, tidak sekadar menara gading saja. Kerangka dimaksud setidaknya dapat menggambarkan metode-metode dan pendekatan-pendekatan yang tepat sehingga dapat membantu para pakar muslim dalam mengatasi masalahmasalah moral dan etika yang sangat dominan di masa sekarang. Kedua,

34Ibid, 117-123. 
perlu suatu kerangka teoritis ilmu dan teknologi yang menggambarkan gaya-gaya dan metode-metode aktivitas ilmiah dan teknologi yang sesuai tinjauan dunia dan mencerminkan nilai dan moral Islam. Ketiga, perlu diciptakan teori-teori sistem pendidikan yang memadukan ciri-ciri terbaik sistem tradisional dan sistem modern. Sistem pendidikan seutuhnya itu secara sentral harus mengacu pada konsep ajaran Islam dengan perpegang pada ajaran tauhid. Di samping itu sistem tersebut harus mampu memenuhi kebutuhan-kebutuhan masyarakat muslim secara multi dimensional masa depan. Dan yang terpenting lagi, pemaknaan pendidikan, mencari ilmu, sebagai pengalaman belajar sepanjang hidup." 35

\section{E. Kesimpulan}

Pesantren telah mengetahui bahkan telah memberikan wahana latihan bagi para santrinya untuk hidup beragama yang berkebangsaan dapat diwujudkan dalam system di lingkungan belajarnya sehingga para santri tidak merasa kesulitan memahami perkembangan ilmu pengetahuan dan persoalan kebangsaan yang cepat. Obyek dan materi; baik ilmu agama maupun sekuler; dalam pendidikan pesantren kemudian menjadi instrumen dalam agar subyek bisa memahami, menyadari dan menyikapinya dalam kehidupan. Pola pendidikan pesantren yang holistik hanya bisa dicapai apabila penegasan kembali bahwa unsur system pendidikan pesantren tidak berorientasi belajar ilmu agama secara tekstual, semua pihak di dalamnya, kyai, guru, ustaz, lurah maupun para santri dan masyarakat bisa belajar hidup bermasyarakat kebangsaan yang konsisten berlandaskan nalar agama.

\section{Daftar Pustaka}

Basri, Husen Hasan. "Keragaman Orientasi Pendidikan Di Pesantren." Dialog Jurnal Penelitiian dan Kajian Keagamaan 37, no. 2 (2014): 209-222.

Dhofier, Zamakhsyari. Tradisi Pesantren; Studi tentang Pandangan Hidup Kyai. 4 ed. Jakarta: LP3ES, 1985.

H., Ahmad Nadjib, Muh. Jamaluddin, Hilman Haroen, Taufik Nugroho, dan Paiman Paiman. "Penanaman Nilai-Nilai Kemasyarakatan Di Pesantren Modern.” Nuansa Akademik: Jurnal Pembangunan

35Ziauddin Sardar, Rekayasa Masa Depan Peradaban Muslim, terj. Rahmani Astuti, (Bandung: Mizan, 1986), 280-281. 
Masyarakat 4, no. 1 (Juni 25, 2019): 17-32.

Imroatun, Imroatun. "Kontribusi Lembaga Pendidikan Agama Islam Dalam Penguatan Identitas Bangsa." Jurnal Ilmiah Bidang pendidikan Studia Didaktika 8, no. 1 (2016).

Madjid, Nur Cholish. Bilik-bilik Pesantren; Sebuah Potret Perjalanan. Jakarta: Paramadina, 2010.

Musaropah, Umi. "Kharisma Kyai Dalam Organisasi Pendidikan Pesantren Tradisional." Ulumuddin: Jurnal Ilmu-ilmu Keislaman 8, no. 2 (2018): 141-155.

Musaropah, Umi, Muhamad Mahali, Daluti Delimanugari, Agus Suprianto, dan Taufik Nugroho. "Internalisasi Nilai Luhur Ahlu Sunnah wal Jama'ah Bagi Pengembangan Karakter kebangsaan Di Perguruan Tinggi.” Nuansa Akademik: Jurnal Pembangunan Masyarakat 5, no. 2 (Desember 26, 2020): 89-102.

Musodiqin, Muhammad, Difla Nadjih, dan Taufik Nugroho. "Implementasi Sorogan Dalam Pembelajaran Al-Qur'an Pada Madrasah Diniyah Takmiliyah.” Ulumuddin: Jurnal Ilmu-ilmu Keislaman 7, no. 1 (2017).

Nugroho, Taufik. "Analisis Manajemen Pendidikan Terhadap Kualitas Madrasah Indonesia." Ulumuddin: Jurnal Ilmu-ilmu Keislaman 6, no. 2 (2016): 80-87.

- - . "Reorientasi Peranan Pesantren Pada Era Pembangunan Menuju Partisipasi Pemberdayaan Masyarakat Bawah.” Ulumuddin: Jurnal Ilmu-ilmu Keislaman 7, no. 2 (2017): 147-155.

Raharjo, M. Dawam, ed. Pesantren dan Pembaharuan. 5 ed. Jakarta: LP3ES, 1985.

Solo, Ahlan Abdullah, Taufik Nugroho, dan Difla Nadjih. "Upaya Santri Dalam Pemeliharaan Hafal Al- Qur'an Di MANU Kota Gede Yogyakarta.” Ulumuddin: Jurnal Ilmu-ilmu Keislaman 8, no. 2 (2018): 131-140.

Syafei, Makhmud. Masjid Dalam Prespektif Sejarah Dan Hukum Islam. Bandung, n.d.

Ziemek, Manfred. Pesantren Dalam Perubahan Sosial. Jakarta: P3M, 1986. 